\title{
Sexual Harassment and Women at the Workplace: A Sociological Review
}

\author{
Amita Mor* and Jatesh Kathpalia \\ Department of Sociology, College of Basic Sciences and Humanities, \\ CCS HAU, Hisar, Haryana-125004, India \\ *Corresponding author
}

\section{Keywords}

Sexual harassment,

Workplace,

Women,

Prohibition, Causes

Article Info

Accepted:

10 March 2020

Available Online:

10 April 2020

\begin{abstract}
A B S T R A C T
Sexual harassment is one of the significant social issues of all foundations as of late. Various countries have taken measures to manage the outcomes of such an issue. Inappropriate behavior is available in different structures, for example, physical, verbal, non-verbal and visual lewd behavior. The inappropriate behavior brings about infringement of the essential thing privileges of ladies particularly right to correspondence under article 14 and 15 of the Indian constitution and her entitlement to life and to live with nobility under article 21 of the constitution. Lewd behavior has indicated a consistent increment from a decade ago to the present situation with $29.20 \%$ cases enlisted in the year 2015 and which brought about infringement of fundamental invulnerabilities of ladies at working environment. There were 12,860 charges filed with the EEOC (Equal Employment Opportunity Commission) alleging sex-based harassment in 2016. One in three women face harassment in the workplace yet 70 percent of women say they have never reported it. Barely a person feel that the Sexual Harassment of Women at workplace (Prevention, Prohibition and Redressal) Act, 2013 is been so vital and powerful to the working ladies and the working environment, finding a way or solution for punishing such kind of offenses. This is a review-based paper. So, secondary data has been used to sociological aspects. Women suffer with sexual harassment at workplace through literatures and secondary data are the target of the study. The objective of this paper is to learn about the sexual harassment against woman in India and to find the causes of harassment against woman at workplaces and to suggest few recommendations to tackle the issue of sexual harassment of women at workplace. Sexual harassment is at an alarming stage and needs an immediate attention by the organizations as well as government.
\end{abstract}

\section{Introduction}

Sexual harassment is the declaration of undesirable human relationship and it isn't only the infringement of respect, immaculate to government regulated assets and reasonable to calm closeness ensured by law.
Inappropriate behavior is genuinely hurting and makes an awful, inadequate air at the working environment (Thomas, 2015). It is a perilous issue found in the work environment in India which has changed into the fundamental factor for diminishing working life (Sengar, 2016). The female work theory 
has decreased stood apart from men since two decades from 1981 to 2001(Crisp, 2018).

Sexual harassment is pointless irritation of sexual necessities with regards to relationship of inconsistent force (MacKinnon,1979) which incorporates physical contact, interest for sexual favors, demonstrating hued comments and sex entertainment even verbal and non-verbal direct of sexual nature (Section 2(n)). By inappropriate behavior the ladies encounters both physical and mental torment. The sexual harassment has taken new shapes while the women have entered in work power. The partners and heads researched each likelihood to trouble the women at workplace on wide range and scale (Venumadhava and Tejashwini, 2015). Salacious conduct is extensively seen as a really impudent which makes a demeanor of bothersome and less productive outcome at the workplace by this sense it has been seen exhaustively as most disturbing sort of ruthlessness since long (Thomas, A. 2015). The Sex Discrimination Act 1984 (Cth) characterizes the nature and conditions where inappropriate behavior is unlawful. It is additionally unlawful for an individual to be deceived for making, or proposing to make, a grumbling of inappropriate behavior to the Human Rights and Equal Opportunity Commission.

\section{Examples of sexually harassing behaviour include}

Unwelcome contacting, gazing or scoffing, intriguing remarks or jokes, sexually explicit pictures or posters, unwanted invitations to go out on date, demands for sex, intrusive questions about a person's private life or body, unnecessary familiarity, such as deliberately brushing up against a person, insults or taunts based on sex, explicitly express physical contact and explicitly unequivocal messages or SMS instant messages.
The Vishaka rules completely expresses that it is the obligation of the business or other mindful individual in the working environment to: forestall inappropriate behavior and give systems to the goals of Sexual provocation, which is sorted under two heads i.e.

Quid pro Quo

Hostile work environment

"Quid Pro Quo" literally means "this for that". Applying this to inappropriate behavior, it implies looking for sexual favors or advances in return for work advantages, for example, guarantees of advancement, more significant compensation, scholastic headways and so forth. This sort of inappropriate behavior generally holds a lady to deliver as her refusal to consent to a 'demand' can be met with retaliatory activity, for example, rejection, downgrade, notices, discolored work record and troublesome work conditions.

"Hostile work environment" is a less clear yet increasingly inescapable type of lewd behavior. It regularly includes states of work or conduct towards a female specialist, which make it terrible for her to be there. While the specialist is never guaranteed or denied anything right now, inappropriate behavior happens just on the grounds that she is a lady (Act, 2013).

As indicated by Vishaka v. Province of Rajastha case, the various basics of sexual harassment incorporate physical contact including spontaneous and clear sexual offers, request or solicitation for sexual favors, passing explicitly hued remarks, indicating sex entertainment against will and ultimately, some other unwelcome physical, verbal or non-verbal lead of sexual nature (Kaushik, 2015).

McLaughlin et al., (2012) advocate that lewd behavior is utilized as an equalizer against 
ladies in power, as opposed to prompted by sexual want. They battle this is one route for men to command and control ladies, who are viewed as non-conventionalist and have ascended to situate which have been generally involved by men. Most working ladies face inappropriate behavior at working environment in some shape or different (Gulyani, 2014).

The rate of sexual harassment is growing well-ordered and the law which is adequately strict ought to be totally associated (Tinkler, 2011). Sexual harassment defined as "hostile environment", which refers to sex-related behaviours which make the person being harassed feel scratchy, thereby making an unapproachable working environment (Smolensky and Kleiner, 2003).

Chawla (2017) expressed that life in itself changes over problematic when the affiliation you work for styles your life changes snared on torment and sadness. Now and then the work life bother forms into a hazard to the life of the individual being referred to. The examination paper is an endeavor to feature the enthusiastic and mental injury that an individual experiences throughout work environment badgering. It is a push to assist representatives with figuring out how to confront the working environment badgering head on. It is likewise an endeavor to discover approaches to make unfortunate casualty's life somewhat less hopeless as a far as the working environment provocation is concerned.

Sharma, (2017) expressed that sexual harassment at working environment makes an unreliable and threatening workplace, subsequently disheartening ladies' investment in work and antagonistically influencing their social and monetary development.

The obvious and extensive phenomenon of rape and sexual assault are the more usually recognized forms of violence against women based on gender, while the more elusive issue of sexual harassment can be crueler and threatening (Gupta, 2014). According to The Times of India Dec. 12, 2016 of lewd behavior of ladies staff in Directorate General of Civil Aviation (DGCA) home office in Delhi delineate the image of the risky workplace for ladies and uncovers the poor usage of the POSH Act.

Sexual harassment is one of the significant social issues of all foundations as of late. Lewd behavior is available in different structures, for example, physical, verbal, nonverbal and visual inappropriate behavior. In an investigation led in Vellore 100 ladies laborers of various retail parts were concentrated so as to draw out the shrouded challenges in being a working lady particularly that of inappropriate behavior (Doss et al., 2014).

According to the National Crime Records Bureau data, the cases of sexual harassment within office premises doubled from 57 in 2014 to 119 in 2015 . Besides, there has also been a surge of $51 \%$ in sexual harassment cases at other places related to work from 469 in 2014 to 714 in 2015 (Chachra, 2017).

Kalof et al., (2001) uncovered that out of 525 students, around 40 percent of the ladies and 28.7 percent of the men had been explicitly bugged by a school teacher or educator inside or outside the grounds.

Shetty and Nithyashree (2017) detailed that 210 workers showed that lion's share $(20 \%)$ were between the age gathering of 30-35 years. Greater part, 63.3\%, of the representatives had intermittent provocation, $8.1 \%$ had gentle badgering, $0.5 \%$ had extreme badgering, and $28.1 \%$ revealed no badgering at the work environment. Zone shrewd investigation demonstrated that most noteworthy conceivable zone among 
members was mental $(15.5 \pm 7.26)$ and the least provocation.

Women endure with badgering at work environment through literary works and optional information was the objective of the examination includes, to get some answers concerning the sorts of provocation against lady at working environments. And to propose scarcely any suggestions to handle the trouble of provocation of young ladies at work environment.

\section{Types of harassment at workplace}

The working environment provocation has numerous different faces yet something that is normal for each situation is that the unnerving reality which will give goose pimples to the more drawn out term representatives. just in the event of a male representative the provocation is inside the kind of counter, names, boisterous attack and so forth yet when it includes a female worker as a rule it's rape.

\section{Sexual orientation bias}

Sexual orientation inclinations additionally can take numerous structures. It are regularly an inside the kind of uncommon consideration which will be either sexual inclination or in a technique or another sex provocation. Now and again, unforeseen consideration or inclination over a male or a female worker additionally can be destructive.

\section{Inclinations on race}

Individuals fill in as a group to fulfill the allotted targets and objectives. Over the span of accomplishing targets in the event that one runs over remarks that are bolstered prejudice the expert targets lose their essentialness.

\section{Obnoxious attack}

Severe, impolite and mortifying comments that are loaded up with mockery continue pulling you in reverse and once you find a good pace such remarks from individuals that are consistently there to observe your endeavors life turns into a falsehood.

Hollering at associates or subordinates, steady analysis, names, utilizing foul or harsh language can never bolster a situation that is sound for proficient development and progression.

\section{Holding and taking out grudges}

Provocation is for the most part the result of the feelings of spite that we hold against one another in proficient life. It very well may be either to show somebody down or with an end rationale to get advancement in office. Much of the time managers or the quick supervisors take points of interest of the position allocated to them and roll out ill-conceived improvements in the work routine of their representatives and that too with a sole thought process to hassle them. Workers who are in need endure such uninterested and rude mentality which further spurs the business to be constant.

\section{Sexual abuse}

One of the most exceedingly awful types of working environment disturbances is sexual progression that carries an awful name to the work environment condition.

In spite of the fact that the report of inappropriate behavior in work environment to a great extent relies on the way of life settings of an individual and still, at the end of the day there are endless cases that show us the genuine essence of our edified society 


\section{Passionate harassment}

As contrast with the physical badgering the enthusiastic provocation doesn't get effortlessly saw however we can truly not stay away from the negative effects of it. Working environment harassing has been the reasons of work environment clashes much of the time. It incorporates dishonest complaints, cold treatment, antagonistic glares, hollering, yelling and task of preposterous remaining burden to the people in question. An examination drove by Workplace Bullying Institute/Zog by had reported that 27 percent agent had been the losses of workplace harassing in past and 7 percent were at the same time standing up to it (Yamada and David, 2014).

\begin{tabular}{|l|l|l|}
\hline Some statistics & & \\
\hline $\begin{array}{l}\text { Types of } \\
\text { harassment }\end{array}$ & Experienced & Witnessed \\
\hline $\begin{array}{l}\text { Verbal } \\
\text { harassment }\end{array}$ & $56.9 \%$ & $65.3 \%$ \\
\hline $\begin{array}{l}\text { Sexual } \\
\text { harassment that } \\
\text { includes physical } \\
\text { contact }\end{array}$ & $33.0 \%$ & $39.4 \%$ \\
\hline $\begin{array}{l}\text { Physical } \\
\text { harassment }\end{array}$ & $8.5 \%$ & $14.3 \%$ \\
\hline $\begin{array}{l}\text { Emotional } \\
\text { harassment }\end{array}$ & $55.8 \%$ & $58.8 \%$ \\
\hline Sarsman & & \\
\hline
\end{tabular}

Source: Nan DeMars Tata Management Training Centre

Opportunity Commission in the United States has built up a valuable meaning of lewd behavior in the accompanying manner, "Unwelcome sexual advances, requests for sexual favours and other verbal or physical conduct of sexual nature constitutes sexual harassment when: 1) Submission to such conduct is made either explicitly or implicitly a term or condition of an individual's employment, 2) Submission to or reject of such conduct by an individual is used as the basis for employment decisions affecting such individual" (Joshi and Nachison, 1996).

\section{Cases of sexual harassment including} sexual harassment at workplace

The National Crime Records Bureau (NCRB) has begun gathering information with respect to lewd behavior at work environment under the class of affront to the humility of ladies (segment 509 of IPC) at office premises since 2014. An absolute number of 57, 119 and 142 cases were enrolled during 2014, 2015 and 2016 separately under this.

To the extent that the protests enrolled with the National Commission for Women (NCW) are worried, there is an expansion in grumblings enlisted under class 'Inappropriate behavior incorporates Sexual provocation at Workplace'. The figures representing number of such grievances listed during the last three years is given below:

\begin{tabular}{|l|l|l|}
\hline Year & 2016 & 2017 \\
\hline No. of cases & 539 & 570 \\
\hline
\end{tabular}

During the recent calendar year, the NCW has started keeping data under exact category of grievances of 'Sexual Harassment of Women at Workplace'. The data indicating number ofsuch cases listed during January, 2019 is given below:

\begin{tabular}{|l|l|}
\hline Category & Registered cases \\
\hline No. of cases & 29 \\
\hline
\end{tabular}

08 FEB 2019 6:06PM by PIB Delhi

Doss, et al., (2014) stated that more than 50\% of the accused did not answer when sexually harassed. This may be due to a sense of embarrassment, poor economic circumstances or an anxiety of social humiliation. 


\section{Laws for sexual harassment}

Underneath this sexual harassment of women at workplace act, 2013 as this regulation offers a civil remedy that if the harassment is of criminal nature, the complaint is to be filed with the police:

Under area 354A of IPC, detainment for one year which may reach out to five years and with the fine

Under area 509 of IPC if the individual express any word or do any such signal or act with the goal to affront the humility of a lady the discipline given is straightforward detainment for a long time and with the fine and

Section 294 arrangements with disgusting acts and tunes at open spots.

In the abstract given by the National Crime Reports Bureau of Home Affairs the crime percentage for inappropriate behavior is 0.7 with the occurrence happening 8,570. Andhra Pradesh has detailed 42.7\% (3,658 cases) trailed by Maharashtra $12.5 \% \quad(1,071$ instances) of absolute occurrences during the year 2011. Andhra Pradesh has detailed the most noteworthy crime percentage (4.3) when contrasted with the National normal of 0.7. The episodes of wrong doing against ladies was diminishing from 2009 to 2011 as it was 11,009 of every $2009,9,961$ of every 2010 and 8,570 out of 2011 .

\section{Suggestions and recommendations}

All the associations should prepare their workers about lewd behavior and its lawful ramifications where it is appropriate.

Create a composed arrangement for zero resistance in inappropriate behavior cases. Figure and spread inner arrangement, presentations and banners for preclusion, counteraction and Redressal of lewd behavior in the establishment.

Legal mindfulness projects ought to be masterminded and sorted out by every office under government and private parts which will well-known the ladies workers about their privileges and benefits.

Clearly characterize 'Lewd behavior' so nobody can claims numbness concerning what adds up to improper conduct adding up to inappropriate behavior.

Organize courses, workshops and mindfulness programs at normal interims for sharpening representatives on the issues and ramifications of work environment lewd activities. Give models and portrayals with respect to what adds up to inappropriate behavior.

Sexual badgering ought to be positively examined at laborers' gatherings, boss worker gatherings, and so forth. Treat inappropriate behavior as unfortunate behavior and start administration rules and disciplinary procedures against the supposed individual.

Declare the synthesis and constitution and contact subtleties of inner objection advisory group (ICC) and its individuals.

In today's modern society where ladies have fired taking up positions of authority which may be a test to the men who are in a propensity for being in the male centric culture and subsequently attempt to command them through bugging them. In India Sexual badgering at the work environment is still particularly in presence today like never before. Study uncovered that inappropriate behavior is an ongoing risen social shrewdness which is developing with outrageous speed and gives a lot of worry to the specialists about the issue.

The present examination likewise sets out the causes that have given unconstrained increment in the lewd behavior cases in India. Strength of men at work environment ought to 
be put under stack by giving ladies an additional edge for advancements and different benefits and it without a doubt cut down the quantity of cases detailed every year.

The present examination additionally investigation the information of National Crime Records Bureau which was discharged by the office in 2016 and a broad study was done about the cases revealed in the report. What's more, in nutshell is seen that the instances of lewd behavior of ladies at work place in India are expanding step by step. What's more, the need is to give such an instrument, that could all the more likely end the circumstance and diminish down the quantity of cases.

\section{References}

Chawla, K. P.(2017). Psychological Aspects of Workplace Harassment and Preventive Measures: A Review. International Journal of Management, $8(4), 82-$

87.http://www.iaeme.com/IJM/issues. asp?JType $=I J M \& V T y p e=8 \&$ IType $=4$

Crime in India (2011). National Crime Records Bureau, Ministry of Home Affairs

Crisp, B. R. (2018). From distance to online education: Two decades of remaining responsive by one university social work programme. Social Work in Education, 1-13.

Doss, E. N., Mukherjee, P. K. and Arvin, M. K. (2014). a study on sexual harassment among women workers at work place in Vellore city. Indian Journal of Applied Research, Vol. 4(12), 35-37.

Heather, M., Uggen, C. and Blackstone, A. (2012). Sexual harassment, workplace authority and the paradox of power. American Sociological Review, Vol.
77, 625-48.

Joshi, J. H. and Nachison, J. (1996). Sexual Harassment in the Workplace How to Recognize; How to Deal It. CGIAR Gender Program, working paper, No. 13.

Justine, T. E. (2011). Resisting the Enforcement of Sexual Harassment Law. Law \& Social Inquiry: Journal of the American Bar Foundation, Vol. $37(1), 1-24$.

Kalof, L., Kimberly L. E., Jennifer, L. M. and Rob, J. K. (2001). The influence of race and gender on student self-reports of sexual harassment by college professors. Gender and Society, Vol. 15, 282-302.

MacKinnon, C. (1979). Sexual Harassment of Working Women: A Case of Sex Discrimination. New Haven, Yale University Press.

Manjinder, G. (2014). Protection of Women from Sexual Harassment at Workplace: Some Reflections." Asian Journal of Research in Social Sciences and Humanities, vol. 4(10). Pp. 364.

Pereira, M. P. J. and Rodrigues, E. J. (2014). Sexual Harassment at Work Place in India Medico Legal Aspects. $J$. Indian Forensic Med., Vol. 306(4).

Sahgal, P. and Dang, A. (2017). Sexual Harassment at Workplace Experiences of Women Managers and Organisations. Economic \& Political Weekly EPW, Vol. 51(22), 49-57.

Section 2(n) of the Sexual Harassment of Women at Workplace (Prevention, Prohibition and Redresal) Act, 2013.

Sengar, A. S. (2016). Analysis on sexual harassment of women at workplace. International Journal of Law and Legal Jurisprudence Studies, Vol. $3(1)$.

Shetty, A.P, Nithyashree, B.V. (2017). Workplace harassment among employees: An explorative study. 
Arch Med Health Sci;5:187-90.

Smolensky, E. and Kleiner, B. H. (2003). How to prevent sexual harassment in the workplace. Equal Opportunities International.

The Indian Penal Code, 1872 (Act No. 45 of 1860).

The Times of India, December 12, 2016.

Thomas, A. (2015). Incidents of sexual harassment at educational institutions in India: preventive measures and grievance handling. International Journal of Research and Review in Health Sciences Recent Advances in Multidisciplinary Research, Vol. 2(3),
0317-0322.

Venumadhava, G.S. and Tejashwini, M. (2015). Sexual Harassment of Women at workplace. International Journal of Advanced Research, Vol. 3(5), 11361139.

Yamada, David. Promoting healthy, productive, and socially responsible workplaces. 2014 Warns-Render Institute University of Louisville, Louis D. Brandeis School of Law. New Workplace Institute: promoting healthy, productive, and socially responsible workplaces.

\section{How to cite this article:}

Amita Mor and Jatesh Kathpalia. 2020. Sexual Harassment and Women at the Workplace: A Sociological Review. Int.J.Curr.Microbiol.App.Sci. 9(04): 1014-1021. doi: https://doi.org/10.20546/ijcmas.2020.904.120 